\title{
THE BASIS FOR INITIATING THE EURASIAN INTEGRATION OF THE AGRICULTURAL SECTOR
}

\author{
Sayabek Ziyadin \\ Dr., Ph.D in Economics, Professor, al-Farabi Kazakh National University. \\ Address: 71 al-Farabi Ave., 050040 Almaty, Republic of Kazakhstan. \\ E-mail:sayabekz@gmail.com
}

\section{Natalya Kabasheva}

$\mathrm{PhD}$ in Economics, Associate Professor of Finance Department, "Financial Academy" JSC. The Ministry of Finance of the Republic of Kazakhstan Address: 92 Maulenova Str., 480012 Almaty, Republic of Kazakhstan.

E-mail: kabasheva_nataly@mail.ru

\begin{abstract}
This article discusses the basics of the integration of Eurasia's agricultural sector, based on the integration process between the European Union (EU) and Asian countries. The EU's agricultural integration has to be regarded as an innovative, large-scale project. The transformation of the EU's agricultural market has proven to be a complex agricultural integration that combines multiple ideological, financial, and political interests. Throughout the period of the EU's agricultural integration, its financial instruments and structured management were stable and, consequently, the integration was effective. However, the development stages of the ecological agriculture projects (EAP) study showed that the formation of a competitive EU agricultural market had some disadvantages. The complexity of the development of the agricultural market in Asian countries, including Kazakhstan and China, results from the fact that, unlike Europe, the Asian countries are at significantly different levels of development with respect to their economic, cultural, and political systems.
\end{abstract}

Keywords: integration; innovation; management; marketing; policy; agriculture.

Citation: Ziyadin, S. \& Kabasheva, N. (2018). The Basis for Initiating the Eurasian Integration of the Agricultural Sector. Public Administration Issues, Special Issue (electronic edition), pp. 56-67 (in English); DOI: 10.17323/1999-5431-2018-0-5-56-67.

\section{Introduction}

The European Union (EU), which currently comprises 28 states, created a new economic market. The key to its development is the economic integration of the EU countries in the same economic space. For more than 50 years, Europe conducted numerous integration processes, which were manifested in the processes of unifying the socioeconomic, institutional, and legal systems of the EU Member States. Today, we must carefully study the experience of the EU's ag- 
ricultural integration within the framework of the Common Agricultural Policy (CAP), its historical background, its advantages, and its disadvantages. According to the survey, it is necessary to identify the basic features of the Eurasian integration of the agricultural sector. The primary reason for this study is that Europe has not only integrated the structures of 28 European countries' agricultural sectors, it has also created the only international structure to overcome the difficulties and obstacles that stand in the way of a competitive agricultural market.

Investigation of the agricultural integration of the European Union and Asian countries. The EU is an inter-regional integration union of states that has strong supranational elements, manifested in the design and implementation of a common policy in trade, agriculture, transport, and other economic areas. In 1957, six countries signed the Treaty that established the European Economic Community. The EU's CAP is based on that treaty, which has been in force for more than 50 years.

According to Borisas Melnikas, the EU's cohesion is a particularly important factor in its processes of integration, agrarian integration, and enlargement (Melnikas, 2013).

All of the EU's agricultural integration processes began following the emergence and functioning of the CAP. The EU's ecological agriculture projects (EAP) constitute a system of EU agricultural subsidies to participating countries.

During the integration period, many reforms and changes have led to the modification of the CAP. While approaching a new financial period (after 2014), which requires the completion of the initiated reforms, the EAP has been subject to both active political decisions and ideological modifications because the policy's original purpose no longer exists. Effective recommendations for submission to the required investigation of possible stages of the development of the agricultural integration of the EAC allow the system to evaluate the content and results of development policies.

The primary objectives of the CAP are to guarantee the production of sufficient food and to ensure a fair standard of living for people engaged in agriculture in Europe (Lissitsa, Luke, Gagalyuk \& Kvasha, 2006).

The background and reasons for agrarian integration arise out of the fact that all of the parties involved in the integration process have their own interests and attempt to solve their own urgent problems through joint efforts. Similar reasons include the following:

- The desire to provide access to a wider variety of agricultural produce;

- Access to cheaper inputs;

- Improved trading conditions;

- $\quad$ Reduced costs due to "economies of scale" in production;

- The achievement of sustainable economic growth in the agricultural sector; and

- Foreign direct investment, which is attractive to large markets.

The primary CAP mechanisms in the EU include guaranteed total prices in euros and overall organization of the markets (Ritson \& Harvey, 1997). This financial integration has not only reduced friction among intergovernmental financial institutions and investors in manufacturers of agricultural products but also ensured fair competition by eliminating the risk of variations in prices caused by currency exchange rates. 
Jordi Mondria and Thomas Wu (2013) address the problems of imperfect financial integration. They note that imperfect financial integration is the result of development problems in all economic sectors, including agriculture. Following the example of the EU, Mondria and Wu establish a pricing model that provides stability by investing in assets that, due to small downgrades, have resulted in financial friction in interstate relations.

Some authors distinguish among ambiguous stages of the CAP. Some fix chronological events without specifically classifying them into stages or distributing them in time (Nello, 2008; Fennel, 1997). Others (Tracy, 1998; Navickas, 2003) identify only the initial stages of development of the CAP, omitting separate tools and indicators.

On the basis of the proposed stages of the EAC's formation by authors such as Nello (2008), Navickas (2003), Tracy (1998), and Fennel (1997), the stages of CAP development are proposed, which consist of the following processes of agricultural integration:

The first stage (1962-1973 and 1973-1977) involved providing EU citizens with the most appropriate food through public procurement to encourage increased production volumes. Purchase prices were fixed at a high level, import restrictions were not. Because at that time the EU had brought together nine countries, there was a need to coordinate their common policies on regulating the prices of agricultural products, to offer tools for market regulation, and to formulate the principles of establishing purchase prices and volumes (Zobbe, 2001). Participants in the agricultural sector received large subsidies. The total EU budget expenditure on agriculture was very high, and the high degree of support for the production of particular agricultural products led to overproduction, resulting in taxes and subsidies in addition to the CAP, which EU Member States were permitted (to some extent), independent of the general policy (Gopinath, Mullen \& Gulati, 2004).

The second stage (1978-1984) involved the strict regulation of purchase prices, limiting overproduction of agricultural products and supply to the market. In this stage, the EU significantly reduced the use of tools to support market prices and strengthened fiscal discipline related to the use of its general budget. This stage also involved the introduction of export subsidies, which created more favorable price conditions for the implementation of agricultural goods in foreign markets. The adopted measures were deemed insufficient because it was not possible to reduce overproduction. In 1981, Greece joined the EU.

During the third phase (1984-1988), the EU made efforts to further reduce the volume of agricultural products by regulating purchase prices, implementing domestic market-protecting tax policies, and imposing milk-production quotas. Those quotas changed the CAP, which first approved quantitative restrictions on the production of particular commodities. Milk quotas were set individually for each Member State, and Community subsidies were paid only on amounts within the quota. In 1986, Spain and Portugal joined the EU. Their views on the need to integrate the Member States are expressed by Emmanuelle Lavallée and Vincent Vicard (2013), who recognize that transferring political boundaries sharply reduces world trade flows.

During the fourth stage (1988-1992), the EU united 12 countries, stabilized the supply of essential agricultural products in the internal market, stimulated the 
development of a range of high-quality products, supported farms located in less favorable agricultural regions while farmers determined the need for environmental preservation, and financially supported the processing of particular types of agricultural products (The Green Paper, 1985).

Quotas for cereal products and oil plants. During the fourth stage, new methods of fixed financial support emerged. Those methods should have prompted structural changes in the agricultural sector as previously introduced EU subsidies were prematurely retired, including support for manufacturers' use of extensive agricultural technology in less-productive regions. Farmers established a requirement to engage in crop rotation to ensure the land's natural recovery of its yield every year by leaving $10 \%$ of it unused.

During the previous three stages of the EAP, its costs increased significantly in accordance with the EU's growth and the range of the instruments that it used.

The EU then decided to gradually reduce the cost of the CAP with the goal of not exceeding $0.65 \%$ of the GDP of all of the Member States (Drozdz \& Radzevicius, 2010). For several years, it was possible to reduce the cost of the CAP, but it later rose again, prompting the inevitable need to radically reform the CAP.

During the fifth stage (1992-1996), the EU conducted substantial reforms of the CAP. For example, the MacSharry reform abolished the system of purchaseprice regulation and replaced the direct-payment mechanism of compensation paid per hectare of farmland (Nello, 2008). There were quotas on livestock, such as oxen and sheep, compensation for livestock sold, and livestock payments related to cows and ewes. Farmers were given preconditions and rationally disposed of physical, financial, and natural resources, based on their analyses of real changes in the market, to choose the optimal strategy for their own economy and that of a variety of agricultural products (Cardwell, 2004).

In 1995, the EU experienced a second wave of expansion to the East, adding Austria, Sweden, and Finland to the alliance. The first two countries have a long tradition of agricultural activities of an affectional nature, which has had an impact on the content of the CAP. An increasing amount of both attention and financial support was allocated based on strengthening ecologically oriented management through the minimal use of chemicals and the formation of natural parks and reserves.

Assessing the economic aspect of the MacSharry reform, its most important change was its establishment of direct payments per hectare of farmland, which was a prerequisite step towards rebuilding the principles of the agricultural financing system and providing both greater clarity and transparency.

The sixth stage (1997-2003) was the era of "Agenda 2000" (Agenda 2000), which marked the beginning of the EU's liberalization process with respect to the production of agricultural products.

Defined plan to continue reforms. The need to reform the EU's agricultural policy caused many problems. Agricultural subsidies covered approximately $50 \%$ of the cost of production, or approximately half of the EU's annual budget (Korol'kov, 2002). EU countries identified new principles for the CAP.

This new phase of decentralization was accompanied by a simplification of the CAP's rural development rules and the rejection of a large number of instruc- 
tions, particularly with respect to crop production. Legislation became clearer, more transparent, and more accessible. Particular attention was paid to regulating the production and marketing of grain, beef and veal, milk and milk products, tobacco, olive oil, and wine.

The second-most-important main direction in CAP reform related to its development of rural areas, that is, its implementation of an integrated policy using common measures that ensured greater interaction between rural development and prices and market policy within the CAP. The fisheries policy, which was previously part of the CAP, emerged as an independent policy with private financing and independent content.

The seventh stage (2004-2007) is associated with the EU's greatest period of expansion. Ten more countries from Central and Eastern Europe joined. The EU set a strict schedule for direct payments to farmers, fixed specific volumes of payments for each country, delinked payments from production volume, and became instrumental in supporting farmers' income stability. The CAP's primary focus during the seventh stage was its complex ratio of financial support for standards related to environmental protection, food safety and quality, hygiene, sanitation, and the welfare of domestic animals (i.e., cross compliance).

For large farms, the EU introduced modulation, i.e., a percentage reduction in payments. It also increased the volume of funding for rural development.

Market-regulating tools were minimized and left in place only in some sectors, most significantly, dairy products. The EAP's focus was the modernization of agriculture, which was extremely important to the EU's new members. Due to the influx of investment in these new Member States' agricultural sectors, those countries' volume of foreign trade (both within and outside of the EU) intensively increased. Enlargement of the EU increased both foreign trade and trade with the older members of the EU, which at that point was stable and did not show significant growth.

The eighth stage (2007-2013) continued with the 2003 reforms that increased rural development. The EU created a separate regulation that would remain in force from 2007-2013. That regulation identified four main program areas for funding on four axes (Tarybos reglamentas, 2005):

Axis I: The competitiveness of the agricultural sector;

Axis II: Improvement of the natural environment and landscape;

Axis III: Improvement of housing conditions and encouragement of alternative activities in rural areas; and

Axis IV: Implementation of the LEADER method.

Studies have found both advantages and disadvantages to agrarian EU integration within the EAC. The advantages include the following:

- EU agricultural integration should be considered as an innovative, large-scale project implementing agrarian integration;

- Transformation of the EU's agricultural market has proven complex because it combines multiple ideological, financial, and political interests;

- Financial instruments and structured management integration in the EU were stable throughout the period of agricultural integration; and

- The integration was efficient. 
However, CAP implementation also suffered from minor disadvantages caused by intensive economic development, information technology, and human resource capacity, including the following:

- A lack of marketing support for information producers (although agricultural integration in the EU has evolved even without marketing tools);

- Weak landmarks increased producers' attractiveness to investors; and

- The lack of scientific research institutes to address problems related to competitive training and innovation in agricultural integration.

The complexity of the development of the agricultural market in the Asian countries, including Kazakhstan and China, is unlike Europe, where at the beginning of the integration, the economic and political development of the countries involved was relatively comparable. Asian countries have significant differences with respect to the developmental levels of their economic, cultural, and political systems.

A rise in protectionism and regionalism in the global economy; a lack of multilateral cooperation mechanisms in the Asian countries' historical pasts; and geographical, political, economic, and sociocultural differences required the Asian countries to find new approaches to and forms of developing relations, creating their own regional integration association of agricultural markets. Today, the primary task is to lift the Asian countries to a new level, to develop action plans, to develop initiatives, and to eliminate conflict with the high heterogeneity of the Asian region.

The economic rise of China and the high rate of development of other countries in the Asian region have been accompanied by sub-regional, regional, and interregional initiatives intended to promote dialogue related to economic cooperation, including the creation of a common agricultural market. These initiatives have been generated amid growing economic interdependence and complementarity, manifestations of aspirations that consider both national and regional interests. Their implementation leads the world (i.e., the USA and China) in competing for influence in the region. Kazakhstan and China have the potential to exert influence on ongoing processes in the Asian region that are aimed at integrating economies.

China is the largest agricultural country in the world. More than $60 \%$ of the population is rural, and agriculture is the primary source of subsistence. China's social and economic status are primarily determined by two macroeconomic indicators: its population (the largest in the world) and its lack of arable land. Although it has $22 \%$ of the world's population, China has only $7 \%$ of its arable land. The sown area of China is approximately 130 million hectares; China's average farmland per capita is only 10 acres. In the suburbs of major cities, each person accounts for only 0.067 hectares of arable land-in some provinces, 0.04 hectares-which is below the critical level defined by the United Nations Food and Agriculture Organization as 0.053 hectares. (Plows AG, 2009).

By the end of 2014, China's agricultural, rural economy had achieved obvious developmental success, having increased in quality and efficiency while maintaining stability.

According to the data, in 2013, the total volume of collected crops increased by $1.5 \%$ compared to 2012, amounting to 601.94 million pounds. In 2014, China collected a rich grain harvest. Thus, its grain production grew for the 11th consecutive year, reaching 607.1 billion pound (5.16 billion pounds more in 2013). Eleven con- 
secutive years of increasing grain production rapidly grew farmers' incomes. With increased pressure from the economic downturn, a favorable situation persists in the rural economy (Ministry of Agriculture of the People's Republic of China, 2015).

From January to October 2014, the sum of China's imports and exports of agricultural products was 160.14 billion US dollars, $7.0 \%$ more than in the previous year. Exports amounted to 57.88 billion US dollars while imports totalled 102.26 billion US dollars, with an annual growth of $6.7 \%$ and $7.2 \%$, respectively. China has a 44.38 billion US-dollar trade deficit in agriculture, 7.7\% more than the previous year (Ministry of Agriculture of the People's Republic of China, 2015).

At the international level, therefore, the EU and Asia need to discuss further cooperation both to create Eurasian integration and to discuss the formation of a common agricultural market. Methods of implementing agrarian integrationincluding applying proposals based on this study-can be effective in light of the positive experience of EU integration. Those proposals include the following:

1) Introducing integrative processes, systems, and information marketing. On this issue, I previously showed that the primary function of the system of information marketing is to ensure a continuous flow of information from the effective dynamic (depending on the level of integration) and to prepare and adopt additional marketing decisions (Ziyadin, 2012).

2) Introducing factor analysis to determine the degree of investment attractiveness of agrarian market investors and providing quality human resources. Investment analysis is considered by Lubyova and Vojtkova (2014) who analyze the economies of more than 134 countries in terms of multinational manufacturers. They established the dependence of countries' investment attractiveness on their human resources.

3) Creating a research institute to study the problems of introducing modern innovation.

With respect to development and diversification methods, I have previously made the following statements: “... improving the efficiency of production enterprises is achieved through the development of innovative processes ...," and "... diversification activities should not only meet the specific needs of the community, but also improve the efficiency of the use of certain resources ..." (Ziyadin, 2015).

4) Introducing new knowledge about scientific and technological progress in the integration process. Only scientific and technological progress can improve the ability to convert knowledge into innovation (Mersedes, 2014).

\section{Research methodology}

To study organizational and economic measures related to Eurasian integration of the agricultural sector, a rating system, based on two methods, is used: the first method involves a quantitative assessment of the state of the economy; the second is an intuitive method, employed when it is difficult to account for the influence of many factors, owing to their complexity.

A sufficiently accurate and comparable measure is used to assess the conditions of agricultural production in different countries. This allows for the deriva- 
tion of coefficients that indicate the relative impact of different factors in economic development.

Attitude indicator of the effectiveness of the measure for the district to determine the value of the coefficient of economic factors:

$$
K_{j}=\frac{V_{\text {reg. } i}}{N_{\text {reg. } i}}: \frac{V_{c, i}}{N_{c . i}}
$$

where:

$K_{j}$ is the value of the coefficient corresponding to the economic factor.

$I$ is the year period;

$\frac{V_{\text {reg.i }}}{N_{\text {reg.i }}}$ is a measure of efficiency in a given region;

and $\frac{V_{c . i}}{N_{c . i}}$ is the average national efficiency rate.

To determine the level of economic development, we use a comprehensive indicator that takes into account the peculiarities of the economic factors in each case:

$K I, n=\frac{1}{m} \times \sum K j, n$

where:

KI is a factor in economic development;

$m$ is the number of economic factors included in the calculation of the integral indicator; and $K j, n$ is the coefficient of a given economic factor in the $n$-th region.

The methodology used allows us to group regions of importance, based on the proximity of a region to the average of the Eurasian region, as follows:

- The first level is the region most suited to the new economic conditions; it has a KI equal to or greater than 1 .

- The second level is a region that can still control the situation and maintain the potential for economic growth; it has a KI of 0.8 to 1 .

- The third level is the current structure of a region that is not well adapted to the changed management conditions; its $\mathrm{KI}$ is less than 0.8 .

An integrated assessment methodology can be applied to a model of financial-economic, socio-economic and other parameters.

In our view, the main indicators reflecting the degree of integration of the Eurasian region are the parameters of production efficiency, in particular, the volume of production per unit of land area, labor productivity and indicators of a social nature-per capita production of grain, milk, meat, vegetables and potatoes.

The proposed methodological studies are designed to objectively allocate algorithm territory according to the degree of success of industrial and economic activities and to assess the impact of the external environment or change the ratio of internal factors of development.

An integrated indicator enables a comparative assessment of the nature and sustainability of economic development of a territory and eliminates the need to recalculate, using a deflator. 
The evaluation reveals that the agricultural sector of the Eurasian region has attained the second level of economic development. That is, it remains unable to control the situation and maintain the potential for economic growth.

The provision of sustainable agriculture is, in our view, breaking the negative impact of natural and economic factors that destabilize agricultural production.

Factors affect each territory in different ways. As a result of our research, we have identified the following factors in agricultural development, taking into account the most important factor conditions and the key problems in the development of the agrarian and industrial complex (AIC) of Tomsk Oblast:

1. Access to capital (specialized lending programs for the AIC; promotion of the integration of the processing industry with the primary sector; government subsidies).

2. Soil-climate and other natural conditions (conservation and improvement of soil fertility, increased drought resistance of crops, shortening of maturation periods, the struggle with excessive moistening).

3. Innovation (cooperation with regional science, development and introduction of agricultural technology).

4. Domestic demand (the need to improve the level of development of the processing industry, efficient customs import protection).

5. Transportation (the need to develop the transport services sector, increase the density of roads and reduce tariffs for rail transport).

6. Professional associations (collective interests of agricultural producers should represent various community organizations-the association of peasant farms and agricultural cooperatives).

7. Business services (transport, insurance, storage, recycling).

8. Export (advanced export infrastructure (logical centers) and the absence of barriers to entry in the target markets).

9. Time frames (to reduce the outflow of population, enhance entrepreneurial activity and increase knowledge of modern technologies).

10. Legislation (effectively forming the legal basis for the management of subjects, identifying land-use rules, determining the order and size of state support, and other powers).

11. The availability of infrastructure in rural areas (reasonable electricity rates).

12. National traditions and local customs.

To determine the value of each factor identified, we employed the method of peer review (the "pairwise comparison" method), which we adapted to the current situation.

The methodology is used to identify the most important factors, reducing the negative impact of some of them and identifying measures to enhance policy effectiveness, thereby contributing to the sustainable development of the agricultural sector.

The 12 factors identified above are horizontally and vertically arranged. Horizontal factors $\mathrm{Xi}, \mathrm{Xj}$ are arranged vertically as $\mathrm{X} 1=\mathrm{X} \mathrm{1}$; $\mathrm{X} 2=\mathrm{X} 2$; X $3=\mathrm{X} 3$, etc., where each cell of the diagonal has a recorded value of 1 . Appreciated the advantage of the $\mathrm{j}$-th figure compared with i-m. To determine the significance of the various factors, it is recommended that you start with the first factor horizontally and compare it with other factors vertically. The most important factor is given two points. 
Accordingly, between $\mathrm{Xi}$ and $\mathrm{Xj}$ is the identity. The factor used to determine the value of the following formula:

$$
W_{j}=\frac{\sum_{n=1}^{n} X_{j}}{\sum_{n=j}^{n} \sum_{n=i}^{n} X_{i j}}
$$

where:

$W_{j}$ is the weighted value of the indicator;

$\sum_{n=1}^{n} X_{j}$ is the number of assessments (the maximum value should be sought);

$\sum_{n=j}^{n} \sum_{n=i}^{n} X_{i j}$ is the number of assessment points.

The influence of factors on the stability of the agricultural integration development regions of Eurasia is shown by the ranking of the importance of each indicator, taking into account the analysis of the criticality factor conditions of the economic development of Eurasian regions (table).

Table

\section{Determination of the ranking factors}

\begin{tabular}{|c|c|c|c|c|c|c|c|c|c|c|c|c|c|c|c|}
\hline & $\mathbf{1}$ & $\mathbf{2}$ & $\mathbf{3}$ & $\mathbf{4}$ & $\mathbf{5}$ & $\mathbf{6}$ & $\mathbf{7}$ & $\mathbf{8}$ & $\mathbf{9}$ & $\mathbf{1 0}$ & $\mathbf{1 1}$ & $\mathbf{1 2}$ & $\Sigma \boldsymbol{X}_{\boldsymbol{i}}$ & $\boldsymbol{W}_{\boldsymbol{j}}$ & Rank \\
\hline $\mathbf{1}$ & $\mathbf{1}$ & 0 & 2 & 2 & 2 & 2 & 2 & 2 & 2 & 2 & 2 & 0 & 19 & 0.13 & 2 \\
\hline $\mathbf{2}$ & 2 & 1 & 2 & 2 & 2 & 2 & 2 & 2 & 0 & 2 & 2 & 2 & 21 & 0.15 & 1 \\
\hline $\mathbf{3}$ & 0 & 0 & 1 & 2 & 2 & 2 & 2 & 2 & 2 & 2 & 2 & 2 & 19 & 0.13 & 3 \\
\hline $\mathbf{4}$ & 0 & 0 & 0 & 1 & 0 & 2 & 2 & 2 & 0 & 2 & 2 & 2 & 13 & 0.09 & 6 \\
\hline $\mathbf{5}$ & 0 & 0 & 0 & 2 & 1 & 2 & 2 & 2 & 2 & 2 & 2 & 0 & 15 & 0.10 & 5 \\
\hline $\mathbf{6}$ & 0 & 0 & 0 & 0 & 0 & 1 & 2 & 2 & 0 & 2 & 2 & 2 & 11 & 0.08 & 7 \\
\hline $\mathbf{7}$ & 0 & 0 & 0 & 0 & 0 & 0 & 1 & 2 & 0 & 2 & 2 & 2 & 9 & 0.07 & 8 \\
\hline $\mathbf{8}$ & 0 & 0 & 0 & 0 & 0 & 0 & 0 & 1 & 0 & 0 & 0 & 2 & 3 & 0.02 & 12 \\
\hline $\mathbf{9}$ & 0 & 2 & 0 & 2 & 0 & 2 & 2 & 2 & 1 & 0 & 2 & 2 & 15 & 0.10 & 4 \\
\hline $\mathbf{1 0}$ & 0 & 0 & 0 & 0 & 0 & 0 & 0 & 2 & 2 & 1 & 2 & 0 & 7 & 0.05 & 10 \\
\hline $\mathbf{1 1}$ & 0 & 0 & 0 & 0 & 0 & 0 & 0 & 2 & 0 & 0 & 1 & 2 & 5 & 0.03 & 11 \\
\hline $\mathbf{1 2}$ & 2 & 0 & 0 & 0 & 2 & 0 & 0 & 0 & 0 & 2 & 0 & 1 & 7 & 0.05 & 9 \\
\hline $\mathbf{\Sigma} \boldsymbol{X}_{j}$ & 5 & 3 & 5 & 15 & 9 & 15 & 13 & 21 & 9 & 13 & 19 & 17 & 144 & 1.00 & - \\
\hline
\end{tabular}

The most important factors in the sustainable development of agricultural integration in the regions of Eurasia are natural conditions, access to capital, innovation, human resources, etc.

The proposed model is an effective control system of regional development that includes areas of agricultural-industrial integration and organizational and economic measures. The model allows for the use of factors and determines the further development of the integration of agriculture regions of Eurasia. 


\section{Conclusions and suggestions}

Based on this study, we can conclude that the EU's achievement of economic integration within the framework of the CAP is the direct result of its consistentbut-flexible agricultural policy. The model reflecting the EU's many years of experience with the integration process could be the basis for the development and implementation of agrarian integration between the EU and Asia and the creation of a member association to implement this integration, for example, with Kazakhstan, China, and other Asian countries; Kazakhstan and China have relatively competitive economies, raw materials, and agricultural potential.

Kazakhstan plays a major role in agricultural development. Within a relatively short period, Kazakhstan has formed a market-based infrastructure that will improve some portion of the material and technical base, provide working capital to stabilize production, and resolve issues related to marketing agricultural products. It has also formed the foundations of an economic mechanism based on a mixed economy, which will attract investors. In addition, financial leasing has resulted in fleet-replenishment agricultural agroformations, along with the establishment and operation of cooperative regional machine-technological stations, financial and credit unions, and insurance companies that provide a variety of services in the field of agriculture.

Modern economic science cannot yet determine the full impact of the integration processes at the global level. This is not due to the complexity of calculating the results of the integration and plurality effects in time and space.

Further development and improvement of forms of international economic integration may lead to political union, i.e., make integration a confederal state with all the consequences, including the creation of a central government with even more power and authority than supranational institutions of governance.

The most mature form of economic integration of the European Union is based on various treaties and agreements. The EU not only eliminated barriers to the movement of goods, services, capital and labor but also created an economic, monetary and political union.

\section{REFERENCES}

1. Cardwell, M. (2004). The European Model of Agriculture. Oxford: Oxford University Press.

2. Fennel, R. (1997). The Common Agricultural Policy: Continuity and Change. Oxford: Oxford University Press.

3. Gopinath, M., Mullen, K. \& Gulati, A. (2004). Domestic Support to Agriculture in the European Union and the United States: Policy Development since 1996. International Food Policy Research Institute, MTID Discussion Paper, no 75, pp. 107.

4. Jolanta, D. \& Gediminas, R. (2010). Typology of the Developmental Stages of the EU Common Agricultural Policy. Management Theory and Studies for Rural Business and Infrastructure Development, no 21 (2). 
5. Jordi, M. \& Thomas, W. (2013). Imperfect financial integration and asymmetric information: competing explanations of the home bias puzzle? Canadian Journal of Economics, vol. 46, no 1 , pp. 310-337.

6. Korol'kov, A. (2002). EU Agriculture and Agricultural Policy. Moscow: Institute of Europe of the Russian Academy of Sciences

7. Lavallée, E. \& Vicard, V. (2013). National borders matter where one draws the lines too. Canadian Journal of Economics, vol. 46 no 1, pp. 135-153.

8. Lissitsa, A., Luke, O., Gagalyuk, T. \& Kvasha, S. (2006). Common Agricultural Policy of the European Union - the way of formation and functioning principles. Discussion Paper, vol. 57, no 92.

9. Lubyova, M. \& Vojtkova, M. (2014). Analysis of the Degree of the Attractiveness of National Economies for Foreign Investors in the New Globalized Environment. Ekonomicky casopis / Journal of Economics, vol. 62, no 6, pp. 557-578.

10. Melnikas, B. (2013). Cohesion Processes in Internal and External Spaces of the European Union: the New Priorities. Inzinerine Ekonomika-Engineering Economics, vol. 24, no 3, pp. 456-467.

11. Mersedes, R. (2014). Innovation, Knowledge and High-Tech Services in European regions. Inzinerine Ekonomika-Engineering Economics, vol. 25, no 1, pp. 31-39.

12. Navickas, V. (2003). Europos Sajungos Rinku Ypatumai. Kaunas: Technologija.

13. Nello, S.S. (2008). The European Union. Economics, Policies and History. 2nd Ed. University of Siena, Italy.

14. Plows, A.G. (2009). China's experience in the field of food security and its potential application in Russia. Economics of Agriculture of Russia, no 5, pp. 82-85.

15. Ritson C. \& Harvey, D.R. (1997). The Common Agricultural Policy, CAB International.

16. Tracy, M. (1998). Maisto pramone ir žemès ūkis rinkos ekonomikos sąlygomis. Žemès ūkio politika Europos Sajungoje [Food Industry and Agriculture in a Market Economy. Agricultural Policy in the European Union]. Briuselis, Vilnius: Diemedžio Leidykla (in Lithuanian).

17. Ziyadin, S.T. \& Yessenova, G. (2015). Prerequisites for development and diversification of production in industry. The Economic Annals-XXI, no 5-6, pp. 37-40.

18. Ziyadin, S.T. (2012). Prospects for Information Marketing Within Processing Industry of Agroindustrial Sector in the Republic of Kazakhstan. Actual Problems of Economics, vol. 136, no 10, pp. 429-435.

19. Zobbe, H. (2001). The Economic and historical foundation of the Common Agricultural Policy in Europe. Paper presented at Fourth European Historical Economics Society Conference, September, Merton College, Oxford, UK.

\section{OFFICIAL DOCUMENTS:}

1. Ministry of Agriculture of the People's Republic of China (2015). Available at: http://russian. agri.gov.cn/xw/201412/t20141223_24649.htm and http://russian.agri.gov.cn/jcyj/201412/ t20141226_24699.htm

2. Tarybos reglamentas (EB) No. 1698/2005 dèl Europos žemès ūkio fondo kaimo plètrai (EŽÜFKP) paramos kaimo plètrai. $2005 \mathrm{~m}$. rugsèjo $20 \mathrm{~d}$.

3. The Green Paper (1985). Perspectives for the Common agricultural policy. Communication of the Commission to the Council and the Parliament. COM (85) 333. 